\title{
Path Analysis on Determinants of Postpartum Bleeding at Dr. Moewardi Hospital, Central Java
}

\author{
Siti Nur Hidayati'), Uki Retno Budihastuti²), Vitri Widyaningsih3) \\ 1)Masters Program in Public Health, Universitas Sebelas Maret \\ ${ }^{2)}$ Department of Obstetrics and Gynecology, Dr. Moewardi Hospital \\ 3) Faculty of Medicine, Universitas Sebelas Maret
}

\begin{abstract}
Background: Postpartum hemorrhage is bleeding that exceeds $500 \mathrm{ml}$ after the baby is born. The main causes of postpartum bleeding are uterine atony, placental retention, birth canal laceration, and blood clotting abnormalities. Predisposing factors of postpartum hemorrhage are age, parity, anemia, premature rupture of membranes, preeclampsia, prolonged labor, uterine overdistention, labor of action, history of previous bleeding, and distance of pregnancy. Postpartum hemorrhage will cause maternal death if it is not treated immediately. This study aimed to analyze the determinants of postpartum hemorrhage.

Subjects and Method: This study used observational analytic with a case control approach. The study was conducted at Dr. Moewardi, Central Java, from April to May 2019. The total sample was 225 maternity mothers who were selected based on fixed disease sampling by using a ratio of 1: 2 between the case and control groups. The dependent variable was postpartum bleeding. The independent variables were age, parity, anemia, premature rupture of membranes, preeclampsia, prolonged labor, uterine overdistention, action delivery, obstetric history, uterine atony, placental retention, birth canal laceration, and pregnancy distance. Data collection techniques used secondary data medical record records which were analyzed by using path analysis.

Results: Postpartum hemorrhage was directly and positively associated with atonia uterine $(\mathrm{b}=$ $2.46 ; 95 \% \mathrm{CI}=1.53$ to $3.40 ; \mathrm{p}<0.001)$, vaginal laceration $(\mathrm{b}=1.76 ; 95 \% \mathrm{CI}=0.78$ to $2.75 ; \mathrm{p}<0.001)$, poor obstetric history $(b=0.93 ; 95 \% \mathrm{CI}=0.11$ to $1.76 ; \mathrm{p}=0.026)$, and type of labor $(\mathrm{b}=1.70 ; 95 \%$ $\mathrm{CI}=0.94$ to $2.46 ; \mathrm{p}<0.001$ ). It was indirectly affected by preeclampsia, parity, prolonged labor, premature rupture of membrane, age, anemia, uterine overdistention, birth spacing, and placental retention.

Conclusion: Postpartum hemorrhage is directly and positively associated with atonia uterine, vaginal laceration, poor obstetric history, and type of labor. It is indirectly affected by preeclampsia, parity, prolonged labor, premature rupture of membrane, age, anemia, uterine overdistention, birth spacing, and placental retention.
\end{abstract}

Keywords: Postpartum hemorrhage, placental retention, atonia uterine, path analysis

\section{Correspondence:}

Siti Nur Hidayati. Masters Program in Public Health, Universitas Sebelas Maret. Jl. Ir. Sutami 36A, Surakarta 57126, Central Java. Email: sitihidayati58@gmail.com. Mobile: 082133679586.

\begin{tabular}{l}
\hline BACKGROUND \\
Maternal Mortality Rate (MMR) is one of \\
the important indicators of community \\
health status and specifically women's \\
health status. This figure is useful for des- \\
cribing the nutritional status and health of \\
the mother, as well as the level of health \\
care for the mother, especially during preg-
\end{tabular}

nancy, childbirth, and postpartum period. The 2015 Intercensal Population Survey (SUPAS) reports the average of maternal mortality rate (MMR) in Indonesia has reached 305/100,000 live births. This mortality rate declined slightly compared to the 2012 IDHS results which reached $359 / 100,000$ live births so that they did not 
reach the expected target of 102/100,000 live births (Indonesian Health Profile, 2016).

Maternal Mortality Rate (MMR) in Central Java in 2017 was 88.05/ 100,000 live births. The cause of death of maternal mothers in Central Java was hypertension (32.97\%), bleeding (30.37\%), and other causes (19.09\%), whereas Surakarta City MMR has increased from 2016 to 40.6/ 100,00o live births to $70.74 / 100,000$ births live in 2017 so that it did not reach the expected target of 50/100,00o live births. One of the causes of high MMR in Surakarta City was bleeding (Central Java Provincial Health Office, 2017).

Bleeding is the main direct cause of maternal death throughout the world and is followed by hypertension and sepsis. More than two thirds of all bleeding deaths in various countries are caused by post-partum hemorrhage (19.7\%), antepartum bleeding (6.5\%), and intrapartum hemorrhage (o.9\%) (Say et al., 2014). Developing countries such as Indonesia are one of 10 countries that contributed for almost $60 \%$ of maternal deaths in the world (Widyaningsih et al., 2017).

Postpartum hemorrhage is more than $500 \mathrm{ml}$ of bleeding that occurs after vaginal birth or more than $1000 \mathrm{ml}$ after abdominal labor. Severe postpartum hemorrhage is postpartum blood loss for $\geq 1500 \mathrm{ml}$ (Kramer et al., 2011). The main causes of early postpartum bleeding are uterine atony (50\%-60\%), placental retention (16\%-17\%), birth canal laceration (4\%-5\%), and blood disorders (0.5\%-0.8\%). While the risk factors for bleeding include age, parity, anemia, premature rupture of membranes, preeclampsia, other parturition, uterine overdistention, labor with action, previous history of bleeding, and distance of pregnancy (Fauziyah, 2012).
Postpartum hemorrhage is divided into two, namely primary and secondary postpartum hemorrhage. Early or primary postpartum bleeding is bleeding that occurs in the first 24 hours after stage III and is usually caused by uterine atony, birth canal tears, and blood clotting disorders. Secondary postpartum bleeding is bleeding that occurs during puerperium (puerperium) after the first 24 hours III (Carroll et al., 2016).

Prevention efforts on postpartum haemorrhage are carried out by assessing the health status of pregnant women (antenatal); limiting episiotomy, and the implementation of active management of childbirth assistance at delivery with uterotonic administration as soon as the baby is born; fast and precise clamping and cutting of the umbilical cord; gentle withdrawal of the umbilical cord by traction behind the uterus when the uterus contracts properly (Sosa et al., 2009). The need for training is provided to all staff involved in maternity care regarding the assessment of blood loss and monitoring of women after child birth (Knight et al., 2010).

Based on the description above, the authors were interested in conducting a study on postpartum bleeding determinants in Dr. Hospital Moewardi, Central Java.

SUBJECTS AND METHOD
a. Study Design
This was a case control study conducted at
Dr. Moewardi, Surakarta, Central Java,
from April to May 2019.

\section{b. Population and Sample}

The target population of this study was all mothers who were hospitalized at Dr. Moewardi from January to December 2018. The total sample was 225 maternity mothers who were selected based on fixed disease sampling used a ratio of 1: 2 between the case and control groups, namely 75: 150 . 
The case group in this study was a mother who had a copy with postpartum hemorrhage recorded at Dr. Moewardi in JanuaryDecember 2018 and the control group were women who did not have postpartum hemorrhage recorded at Dr. Moewardi Hospital in January-December 2018.

\section{c. Study Variables}

The dependent variable in the study was postpartum hemorrhage. The independent variables were age, parity, distance of pregnancy, obstetrics, anemia, uterine atony, placental retention, birth canal laceration, preeclampsia, uterine overdistention, action delivery, premature rupture of membranes, and prolonged labor.

\section{d. Operational Definition of Variables}

Postpartum hemorrhage defined as more than $500 \mathrm{ml}$ of bleeding experienced by the mother. Data collection uses hospital secondary data. The scale of measurement was continuous, but for the purposes of analyzing, the scale data was converted into a dichotomy.

Age defined as the age of the mother at the time of giving birth to her baby in units of years. Data collection using hospital secondary data. The measurement scale was continuous, but for the sake of analyzing the data, it was converted into a dichotomy.

Parity defined as the number of live births born by a mother. Data collection uses secondary data from the patient's medical record. The scale of measurement was continuous, but for the purposes of analyzing the data, it was converted into a dichotomy.

Pregnancy distance defined as the distance between the current pregnancy and pregnancy in units of years. Data collection uses secondary data from the patient's medical record. The measurement scale was continuous, but for the purposes of analyzing, the scale data was converted into a dichotomy.
Obstetrics defined as a complicating condition during pregnancy, labor, and before postpartum. Data collection in this study used secondary data from patients' medical records. The measurement scale in this study was a dichotomy.

Anemia defined as a postpartum maternal condition with a hemoglobin level of $<11$ gram/ dL. Data collection in this study used secondary data from the patient's medical record. The scale of measurement was continuous, but for the purpose of analyzing, the scale data was converted into a dichotomy.

Uterine atonia defined as a weak state of uterine contractions that causes the uterus to be unable to close open bleeding from the place of implantation of the placenta after the baby and placenta are born. Data collection use secondary data from the patient's medical record. The scale of data measurement was a dichotomy.

Retention of the placenta defined as a condition where the placenta has not been born in part or in full until or exceeding 30 minutes after the baby is born. Data collection used secondary data from the patient's record. The scale of data measurement was a dichotomy.

The laceration of the birth canal defined as a tear that occurs in the perineum, vagina, cervix or uterine spontaneously or as a result of vacuum action, forceps or episiotomy in labor assistance. Data collection used secondary data from the patient's medical record. The scale of data measurement was dichotomy.

Preeclampsia defined as a condition of complications that occurs in the mother characterized by hypertension, edema, and proteinuria after 20 weeks of gestation or immediately after delivery. Data collection used secondary data from the patient's medical record. The scale of measurement was continuous, but for the purposes of 
analyzing, the scale data was converted into a dichotomy.

Uterine overdistention defined as a condition in which the mother experiences excessive uterine enlargement diagnosed with macrosomia and gamelli. Data collection used secondary data from a patient's medical record. The scale of data measurement was a dichotomy.

Childbirth of action defined as labor with an action of certain aids with vacuum (vaginal) and Sectio Caesarea (palpdominan). Data collection used secondary data from the patient's medical record. The scale of data measurement was a dichotomy.

Early rupture of membranes defined as the condition of the mother where the membranes rupture before the signs of inparty. Data collection used secondary data from the patient's medical record. The scale of data measurement was a dichotomy.

Long labor defined as a state of labor that lasts more than 18 hours. Data collection used secondary data from the patient's medical record. The scale of measurement was continuous, but for the purposes of analyzing, the scale data was converted into a dichotomy.

\section{e. Data Analysis}

Univariate analysis aimed to explain each variable, which was the independent variable and the dependent variable. Bivariate analysis in the study was conducted to determine the relationship of the relationship between the dependent variable and independent using the chi-square test. Multivariate data analysis in this study used path analysis to find out direct or indirect relationships.

\section{f. Research Ethics}

Research ethics include namelessness, confidentiality, and ethical approval. This study has obtained ethical permission from the Health Research Ethics Committee of Dr. Moewardi Hospital Surakarta with number: 250/ III / HREC / 2019.

\begin{tabular}{l} 
RESULTS \\
\hline 1. Univariate Analysis \\
The results of univariate analysis aimed to \\
explain and describe the characteristics of \\
each study sample include pregnancy dis- \\
tance, age, uterine atony, parity, obstetric \\
history, preeclampsia, premature rupture of \\
membranes, placental retention, birth canal \\
lacerations, labor delivery, prolonged labor, \\
uterine overdistention, and anemia.
\end{tabular}

\section{Table 1. Sample characteristics (continuous data)}

\begin{tabular}{lccccc}
\hline \multicolumn{1}{c}{ Variables } & n & Mean & SD & Min & Max \\
\hline Pregnancy Distance & 225 & 3.6 & 3.9 & 0 & 15 \\
Age & 225 & 29.1 & 5.8 & 16 & 44 \\
Parity & 225 & 1.8 & 0.8 & 1 & 6 \\
Anemia & 225 & 11.1 & 1.5 & 6 & 14 \\
\hline
\end{tabular}

Table 2. Sample characteristics (categorical data)

\begin{tabular}{lcc}
\hline Characteristics & n & \% \\
\hline Birth spacing & & \\
$\geq 2$ years & 201 & 89.3 \\
$<2$ years & 24 & 10.7 \\
Age & & \\
$20-35$ years old & 170 & 75.6 \\
$<20$ years old or $\geq 35$ years old & 55 & 24.4 \\
Atonia uteri & & \\
No & 184 & 81.8 \\
Yes & 41 & 18.2 \\
\hline
\end{tabular}




\begin{tabular}{lcc}
\hline Parity & & \\
$<4$ times labor & 217 & 96.4 \\
$\geq 4$ times labor & 8.6 \\
Obstetric history & 181 & 80.4 \\
No obstetric history & 44 & 19.6 \\
There is obstetric history & & \\
Preeclampsia & 181 & 80.4 \\
Not preeclampsia & 44 & 19.6 \\
Mild and severe preeclampsia & & \\
Premature rupture of membranes & 125 & 55.6 \\
No & 100 & 44.4 \\
Yes & & 76 \\
Retention of placenta & 171 & 24 \\
No & 54 & 85.3 \\
Yes & & 14.7 \\
Nirth canal lacerations & 192 & 68.4 \\
Yes & 33 & 31.6 \\
Labor action & & \\
No & & 83.6 \\
Pres & 154 & 16.4 \\
No & 71 & \\
Yes & & 96 \\
Nterine overdistention & 188 & 4 \\
Yes & 37 & 62.2 \\
Anemia 11 gram/dL & & 37.8 \\
\hline < gram/dL & 216 & \\
\hline
\end{tabular}

Table 3. Bivariate analysis on the correlates of postpartum hemorrhage

\begin{tabular}{|c|c|c|c|c|c|c|c|c|}
\hline \multirow{3}{*}{ Variables } & \multicolumn{4}{|c|}{ Postpartum Hemorrhage } & \multirow{2}{*}{\multicolumn{2}{|c|}{ Total }} & \multirow{3}{*}{$\mathbf{O R}$} & \multirow{3}{*}{$\mathbf{p}$} \\
\hline & \multicolumn{2}{|c|}{ No } & \multicolumn{2}{|c|}{ Yes } & & & & \\
\hline & $\mathbf{n}$ & $\%$ & $\mathbf{n}$ & $\%$ & $\mathbf{n}$ & $\%$ & & \\
\hline \multicolumn{9}{|l|}{ Pregnancy distance } \\
\hline$\geq 2$ years & 140 & 69.7 & 61 & 30.3 & 201 & 100.0 & \multirow{3}{*}{3.21} & \multirow{3}{*}{0.006} \\
\hline$<$ 2years & 10 & 41.7 & 14 & 58.3 & 24 & 100.0 & & \\
\hline \multicolumn{7}{|l|}{ Age } & & \\
\hline $20-35$ years old & 122 & 71.8 & 48 & 28.2 & 170 & 100.0 & \multirow{2}{*}{2.45} & \multirow{2}{*}{0.004} \\
\hline $\begin{array}{l}<20 \text { or } \geq 35 \text { years old } \\
\text { Atonia uteri }\end{array}$ & 28 & 50.9 & 27 & 49.1 & 55 & 100.0 & & \\
\hline No & 142 & 77.2 & 42 & 22.8 & 184 & 100.0 & \multirow{2}{*}{13.95} & \multirow{2}{*}{$<0.001$} \\
\hline Yes & 8 & 19.5 & 33 & 80.5 & 41 & 100.0 & & \\
\hline \multicolumn{9}{|l|}{ Parity } \\
\hline$<4$ times labor & 149 & 68.7 & 68 & 31.3 & 217 & 100.0 & \multirow{3}{*}{$15 \cdot 34$} & \multirow{3}{*}{0.001} \\
\hline$\geq 4$ times labor & 1 & 12.5 & 7 & 87.5 & 8 & 100.0 & & \\
\hline \multicolumn{7}{|l|}{ Obstetric history } & & \\
\hline No obstetric history & 129 & 71.3 & 52 & 28.7 & 181 & 100.0 & \multirow{3}{*}{2.72} & \multirow{3}{*}{0.003} \\
\hline There is obstetric history & 21 & $47 \cdot 7$ & 23 & 52.3 & 44 & 100.0 & & \\
\hline \multicolumn{7}{|l|}{ Preeclampsia } & & \\
\hline No & 125 & 69.1 & 56 & 30.9 & 181 & 100.0 & \multirow[b]{2}{*}{1.70} & \multirow{2}{*}{0.122} \\
\hline Mild and severe & 25 & 56.8 & 19 & 43.2 & 44 & 100.0 & & \\
\hline
\end{tabular}




\begin{tabular}{|c|c|c|c|c|c|c|c|c|}
\hline \multicolumn{9}{|c|}{$\begin{array}{l}\text { Premature rupture of } \\
\text { membranes }\end{array}$} \\
\hline No & 87 & 69.6 & 38 & 30.4 & 125 & 100.0 & \multirow{2}{*}{1.34} & \multirow{2}{*}{0.297} \\
\hline Yes & 63 & 63.0 & 37 & 37.0 & 100 & 100.0 & & \\
\hline \multicolumn{9}{|c|}{ Retention of placenta } \\
\hline No & 140 & 81.9 & 31 & 18.1 & 171 & 100.0 & \multirow{2}{*}{19.87} & \multirow{2}{*}{$<0.001$} \\
\hline Yes & 10 & 18.5 & 44 & 81.5 & 54 & 100.0 & & \\
\hline \multicolumn{9}{|c|}{ Birth canal lacerations } \\
\hline No & 137 & 71.4 & 55 & 28.6 & 192 & 100.0 & \multirow{3}{*}{3.83} & \multirow{3}{*}{$<0.001$} \\
\hline Yes & 13 & 39.4 & 20 & 60.6 & 33 & 100.0 & & \\
\hline \multicolumn{7}{|l|}{ Labor action } & & \\
\hline No & 117 & 76.0 & 37 & 24.0 & 154 & 100.0 & \multirow{3}{*}{3.64} & \multirow{3}{*}{$<0.001$} \\
\hline Yes & 33 & 46.5 & 38 & 53.5 & 71 & 100.0 & & \\
\hline \multicolumn{7}{|c|}{ Prolonged labor } & & \\
\hline No & 135 & 71.8 & 53 & 28.2 & 188 & 100.0 & & \\
\hline Yes & 15 & 40.5 & 22 & 59.5 & 37 & 100.0 & 3.74 & $<0.001$ \\
\hline \multicolumn{9}{|c|}{ Uterine overdistention } \\
\hline No & 148 & 68.5 & 68 & 31.5 & 216 & 100.0 & \multirow[b]{3}{*}{7.62} & \multirow{4}{*}{0.004} \\
\hline \multirow{2}{*}{ Yes } & 2 & 22.2 & 7 & 77.8 & 9 & 100.0 & & \\
\hline & & & & & & & & \\
\hline$\geq 11 \mathrm{gram} / \mathrm{dL}$ & 111 & 79.3 & 29 & 20.7 & 140 & 100.0 & & \\
\hline$<11 \mathrm{gram} / \mathrm{dL}$ & 39 & $45 \cdot 9$ & 46 & 54.1 & 85 & 100.0 & 4.51 & $<0.001$ \\
\hline
\end{tabular}

\section{Bivariate Analysis}

Table 3 showed the results of bivariate analysis of independent variables and dependent variables. Table 3 showed that the risk of postpartum hemorrhage was higher at a pregnancy distance $<2$ years $(\mathrm{OR}=$ $3.21 ; \mathrm{p}=0.006)$, age $<20$ years or $\geq 35$ years $(\mathrm{OR}=2.45 ; \mathrm{p}=0.004)$, uterine atony $(\mathrm{OR}=$ $13.95 ; \mathrm{p}<0.001)$, parity $\geq 4(\mathrm{OR}=15.34 ; \mathrm{p}=$ o.001), obstetric history $(\mathrm{OR}=2.72 ; \mathrm{p}=$ o.003), preeclampsia $(\mathrm{OR}=1.70 ; \mathrm{p}=0.122)$, premature rupture of membranes $(\mathrm{OR}=$ 1.34; $\mathrm{p}=0.297)$, placental retention $(\mathrm{OR}=$ 19.87; p <0.001), birth laceration ( $\mathrm{OR}=$ 3.83; $\mathrm{p}<0.001)$, labor action $(\mathrm{OR}=3.64$; $\mathrm{p}$ $<0.001)$, prolonged labor $(\mathrm{OR}=3.74 ; \mathrm{p}$
$<0.001)$, uterine overdistention $(\mathrm{OR}=7.62$; $\mathrm{p}=0.004)$, and anemia $<11$ gram $/ \mathrm{dL}(\mathrm{OR}=$ $4.51 ; \mathrm{p}<0.001)$.

\section{Path Analysis \\ a. Model Specification}

Model specifications were used to describe between variables to be examined. Exogenous variables consisted of the distance of pregnancy, preeclampsia, parity, age, placental retention, premature rupture of membranes, uterine over-distention, prolonged labor, birth canal lacerations, and obstetric history. Endogenous variables include anemia, uterine atony, labor delivery, and postpartum bleeding. 
Hidayati et al./ Path Analysis on Determinants of Postpartum Bleeding

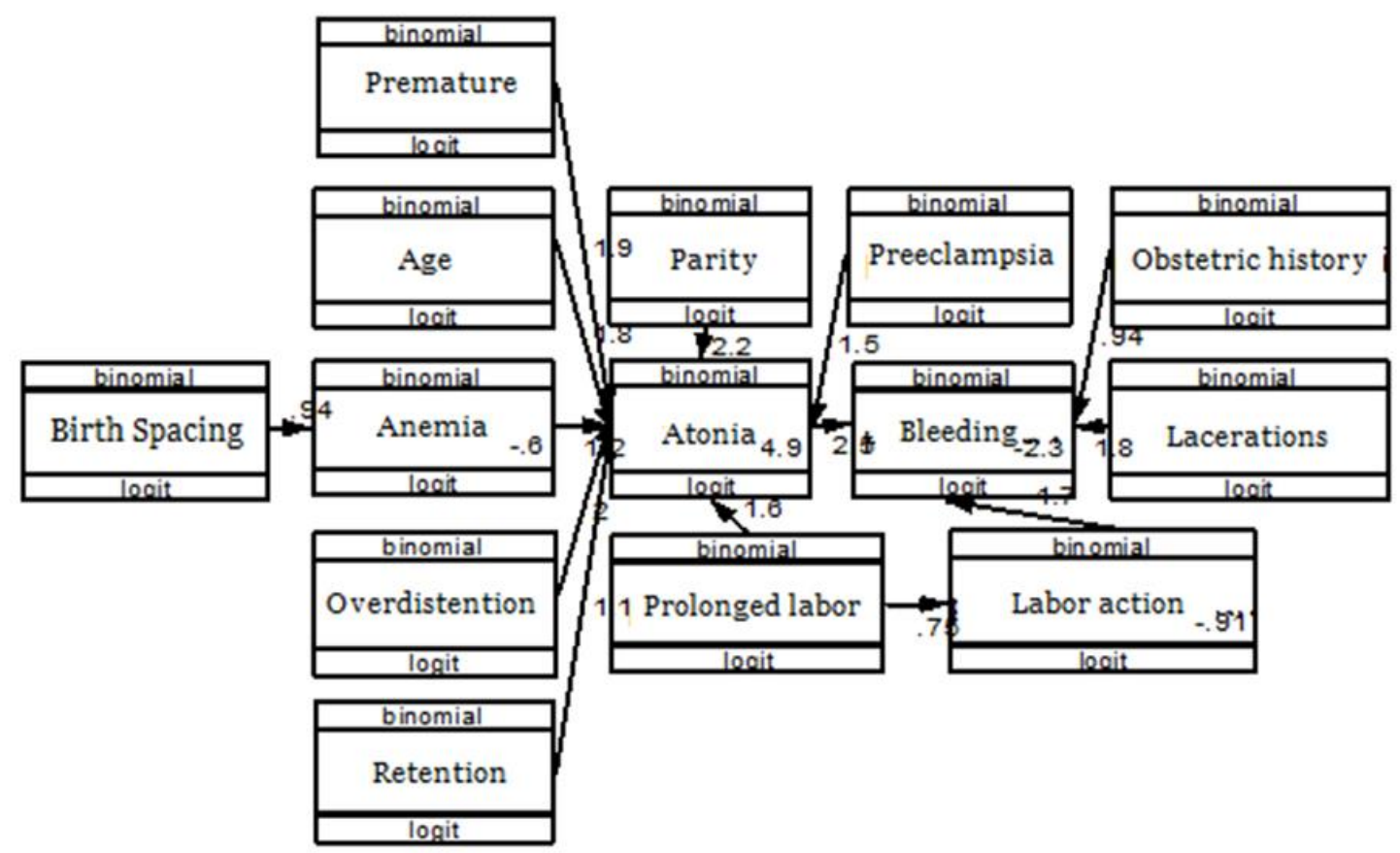

Figure 1. Chart of path analysis with estimated value

Table 4. The results of path analysis

\begin{tabular}{|c|c|c|c|c|c|}
\hline \multirow[b]{2}{*}{ Dependent Variable } & \multirow[b]{2}{*}{ Independent Variable } & \multirow[b]{2}{*}{ b } & \multicolumn{2}{|c|}{ CI (95\%) } & \multirow[b]{2}{*}{$\mathbf{p}$} \\
\hline & & & $\begin{array}{c}\text { Lower } \\
\text { Limit }\end{array}$ & $\begin{array}{l}\text { Upper } \\
\text { Limit }\end{array}$ & \\
\hline \multicolumn{6}{|l|}{ Direct Effect } \\
\hline Postpartum bleeding & Atonia uteri & 2.46 & 1.53 & 3.40 & $<0.001$ \\
\hline Postpartum bleeding & Birth canal lacerations & 1.76 & 0.78 & 2.75 & $<0.001$ \\
\hline Postpartum bleeding & Obstetric history & 0.93 & 0.11 & 1.76 & 0.026 \\
\hline Postpartum bleeding & Labor action & 1.70 & 0.94 & 2.46 & $<0.001$ \\
\hline \multicolumn{6}{|l|}{ Indirect Effect } \\
\hline Uterine atony & Preeclampsia & 1.54 & 0.46 & 2.62 & 0.005 \\
\hline Uterine atony & Parity $\geq 4$ & 2.17 & 0.08 & 4.26 & 0.041 \\
\hline Uterine atony & Prolonged labor & 1.58 & 0.44 & 2.73 & 0.007 \\
\hline Uterine atony & $\begin{array}{l}\text { Premature rupture of } \\
\text { membranes }\end{array}$ & 1.86 & 0.84 & 2.88 & $<0.001$ \\
\hline Uterine atony & Age $<20$ or $\geq 35$ years old & 1.81 & 0.82 & 2.79 & $<0.001$ \\
\hline Uterine atony & Anemia $(<11$ gram/dL) & 1.23 & 0.31 & 2.15 & 0.009 \\
\hline Uterine atony & Uterine overdistention & 1.97 & 0.09 & 3.86 & 0.040 \\
\hline Uterine atony & Retention of placenta & 1.06 & 0.13 & 1.98 & 0.025 \\
\hline Labor action & Prolonged labor & 0.74 & 0.02 & 1.46 & 0.042 \\
\hline Anemia & Birth spacing $<2$ years & 0.94 & 0.07 & 1.80 & 0.032 \\
\hline \multicolumn{6}{|l|}{$\mathrm{N}$ obsevation $=225$} \\
\hline \multicolumn{6}{|l|}{ Log likelihood= -455.2} \\
\hline \multicolumn{6}{|l|}{$\mathrm{AIC}=946.3$} \\
\hline $\mathrm{BIC}=1007.8$ & & & & & \\
\hline
\end{tabular}


Journal of Maternal and Child Health (2019), 4(6): 35-47

https://doi.org/10.26911/thejmch.2019.04.06.04

\section{b. Model Identification}

Measured variable include:

$\begin{array}{ll}\text { 1) } \text { Measured variable } & =14 \\ \text { 2) Endogenous variables } & =10 \\ \text { 3) Exogenous variables } & =4 \\ \text { 4) } \text { Total parameter } & =14\end{array}$

Degree of freedom (df) was as follow:

$\mathrm{df}=($ number of measured variables $\mathrm{x}$ (number of measured variables + 1) / 2) - (endogenous variables + exogenous variables + number of parameters))

$=(14 \times(14+1) / 2)-(10+4+14)$

$=105-28=77$

The result of the degree of freedom (df) was 77 which mean that over identified or path analysis can be done.

Table 4 showed the results of path analysis. Postpartum bleeding has a direct and positive association with uterine atony and it was statistically significant. Postpartum women with uterine atony have logodd to experience post-partum hemorrhage by 2.46 units higher than not uterine atony $(\mathrm{b}=2.46$; CI $95 \%=1.53$ to $3.40 ; \mathrm{p}$ $<0.001)$.

Postpartum hemorrhage had a direct and positive relationship with birth canal lacerations and it was statistically significant. Postpartum women with birth canal lacerations had logodd to experience postpartum hemorrhage by 1.76 units higher than not birth canal lacerations $(b=1.76$; CI $95 \%=0.78$ up to $2.75 ; \mathrm{p}<0.001$ )

Postpartum haemorrhage had a direct and positive relationship with obstetric history and it was statistically significant. Postpartum women with an obstetric history had logodd to experience postpartum hemorrhage by 0.93 units higher than non obstetric history $(\mathrm{b}=0.93$; CI $95 \%=0.11$ to 1.76; $p=0.026$ ).

Postpartum hemorrhage has a direct and positive relationship with labor action and it was statistically significant. Postpartum women with labor of action having logodd to experience post-partum hemorrhage by 1.70 units higher than no act of labor $(\mathrm{b}=1.7 \mathrm{O}$; CI $95 \%=0.94$ to 2.46 ; $\mathrm{p}$ $<0.001)$.

Postpartum hemorrhage has an indirect relationship through uterine atony between preeclampsia, parity, prolonged labor, premature rupture of membranes, age, anemia, uterine overdistention, and plaque retention. Postpartum hemorrhage has an indirect relationship through labor of action with prolonged labor. Postpartum bleeding has an indirect relationship through anemia with the distance of pregnancy.

\section{DISCUSSION \\ 1. The relationship between the dis- tance of pregnancy and postpar- tum hemorrhage}

The results of the analysis showed that there was an indirect relationship between the distance between pregnancy and postpartum bleeding through anemia and it was statistically significant. The study of Briley et al. (2014) stated that the risk of mothers experiencing postpartum hemorrhage with a pregnancy distance of $<2$ years was 2.03 times greater than the pregnancy distance $\geq 2$ years.

The condition of the uterus at $<2$ years of pregnancy was not maximal to provide nutritional reserves for the mother and fetus, so that the mother experienced nutritional disorders and anemia and impaired fetal development. Pregnant women who get anemia would increase the risk of bleeding during labor(Puspitasari et al., 2017).

\section{The relationship between age and postpartum hemorrhage}

The results of the analysis showed that there was an indirect relationship between age and postpartum haemorrhage through uterine atony and it was statistically 
significant. Mothers aged $<20$ years or $\geq 35$ years old can increase the risk of postpartum hemorrhage. Sheldon et al. (2014) showed that there was a relationship between maternal age and post-partum hemorrhage and it was statistically significant.

At the age of $<20$ years old, the mother's uterus and pelvis were not ready to reproduce well, so it need to be wary of experiencing difficult labor and pregnancy poisoning which can result in labor complications. Whereas at the age of 35 years old, the health condition and function of the reproductive organs decreased especially the uterus where the uterine muscles must contract optimally shortly after the placenta was born so that bleeding did not occur (Megasari, 2013).

\section{The relationship between uterine} atony and postpartum hemorrhage The results of the analysis showed that there was a direct association of uterine atony with postpartum hemorrhage and it was statistically significant. Mothers with uterine atony have a higher risk of having postpartum hemorrhage than not uterine atony. The Vendittelli et al. (2016) study stated that uterine atony has the risk of increasing postpartum hemorrhage by $\mathbf{1 . 1 5}$ times. After labor, contractions generally occurred to help suppress the blood vessels that attached to the placenta. The uterine muscles would contract to expel the placenta. If the uterine muscle was not strong enough to contract then bleeding would occur (Yuliawati and Anggraini, 2016).

\section{The relationship between parity and postpartum hemorrhage}

The analysis showed that there was an indirect relationship between parity and postpartum hemorrhage through uterine atony and it was statistically significant. Mothers who have parity $\geq 4$ can increase the risk of postpartum hemorrhage. Tort et al. (2015) stated that there was a relationship between parity and the incidence of postpartum hemorrhage and it was statistically significant.

Parity 1 caused the unpreparedness of mothers in facing labor so that pregnant women were unable to handle complications that occur during pregnancy, childbirth, and postpartum. Whereas parity $>4$ was caused by a disturbance in the elasticity of the uterine muscles, the more often the mother gave birth, the uterus tend to work inefficiently during labor, resulting in failure of compression in the placental implementation site as a result of postpartum hemorrhage (Saadah et al., 2017).

\section{The relationship between obstetric history and postpartum hemor- rhage}

The results of the analysis showed that there was a direct correlation between obstetric history and postpartum hemorrhage and it was statistically significant. Mothers with obstetric history had a risk of having post-partum hemorrhage by 1.76 units higher than without an obstetric history. A study of Nyfløt et al. (2017) stated that mothers who have a previous obstetric history of labor and postpartum period were 3.03 times more likely to experience post partum bleeding.

Obstetrics was related to the outcome of pregnancy and subsequent childbirth. Poor labor history includes a history of IUFD (fetus died in the womb), preterm birth, cesarean section, ante partum bleeding, and post partum(Yuliati et al., 2018).

\section{The relationship between pre- eclampsia and postpartum hemor- rhage}

The results of the analysis showed that there was an indirect relationship between preeclampsia and postpartum hemorrhage through uterine atony and was statistically significant. Nyfløt et al. (2017) stated that 
severe preeclampsia was 3.03 times more likely to increase postpartum hemorrhage. Mothers with preeclampsia would have the chance of postpartum hemorrhage because there was a change in important organs in the body, one of which was endothelial cell dysfunction, namely toxic endothelial cell damage by fat peroxide circulating throughout the body which can damage endothelial cells, so as endothelial cells that were in the uterus, therefore, health personnel need to watch out for postpartum bleeding as a result of myometrial failure to contract.

\section{The relationship between prema- ture rupture of membranes and postpartum hemorrhage}

The results of the analysis showed that there was an indirect relationship of premature rupture of the membranes with postpartum hemorrhage through uterine atony and it was statistically significant. Jekti and Suarthana (2010) stated that mothers with premature rupture of membranes were 2.18 times more likely to have postpartum hemorrhage compared to women without amniotic fluid premature rupture.

The rupture of the membranes would result in infections of the bacteria in the vagina so that it would cause the metabolites of the infectious process through a complex mechanism that would affect uterine muscle metabolism so that it can interfere with post partum uterine contractions which lead to postpartum hemorrhage (Fauziyah, 2012).

\section{The relationship between retention of placenta and postpartum hemor- rhage}

The analysis showed that there was an indirect relationship of retention of the placenta with postpartum hemorrhage through uterine atony and it was statistically significant. Study by Biguzzi et al. (2012) stated that mothers with retention of the placenta were more at risk of increasing post-partum bleeding. Retentiono in part or all plaques in the uterus would interfere with contraction and retraction, causing blood sinuses to remain open and cause postpartum bleeding.

\section{The relationship between birth canal lacerations and postpartum hemorrhage}

The results of the analysis showed that there was a direct relationship between birth lacerations and postpartum hemorrhage and it was statistically significant. A study of Oyelese and Ananth (2010) showed that mothers with birth canal lacerations were 2.4 times more likely to experience postpartum hemorrhage compared to mothers who did not lacerate the birth canal.

Perineal tears occurred in almost all first deliveries and were not too short at the next labor. Birth road tears occurred because excessive birth canal strains and suddenly when the fetus was born. Both the head and shoulders of the fetus can cause tears in the vaginal wall. Sometimes, the tears occurred due to vacuum or forceps. Rips of the birth canal always gave large amounts of bleeding (Yuliawati and Anggraini, 2016).

\section{The relationship betweenlabor action and postpartum hemorr- hage}

This study showed that there was a direct relationship of labor of action with post partum hemorrhage and it was statistically significant. The mother with labor of action were 1.70 units more likely to have postpartum haemorrhage than non-delivery labor. Kramer et al. (2011) study stated that mothers with cesarean delivery have a risk of experiencing postpartum hemorrhage by 1.3 times higher. Mothers with vacuum labor have a risk of 1.6 times to experience postpartum bleeding.

Labor action included maternal vaginal actions, namely vacuum, forceps, episiotomy, and oxytocin drip and the palate, 
cesarean section. Actions in both vaginal and abdominal labor can cause trauma to both the mother and the baby (Puspitasari et al., 2017).

\section{The relationship between pro- longed labor and postpartum he- morrhage}

The results of the analysis showed that there was an indirect relationship between prolonged labor with postpartum hemorrhage through uterine atony and it was statistically significant. The Driessen et al. (2011) study stated that long labor were 1.38 times more likely to increase post-partum bleeding. Long labor caused uterine inertia due to fatigue of the uterine muscles so that the uterus cannot contract properly so that postpartum hemorrhage occurred (Satriyandari and Hariyati, 2017).

\section{The relationship between uterine overdistention and postpartum hemorrhage}

The results of the analysis showed that there was an indirect relationship between uterine overdistention and postpartum hemorrhage through uterine atony and it was statistically significant. The Ononge et al. (2016) study in Uganda showed that multiple pregnancies were 7.66 times more likely to increase postpartum hemorrhage and macrosomia was 2.14 times more likely to increase postpartum hemorrhage. Overdistention of the uterus can cause postpartum hemorrhage because the uterus experienced excessive tension resulting in weak uterine contractions and triggered postpartum hemorrhage.

\section{The relationship between anemia and postpartum hemorrhage}

The results of the analysis showed that there was an indirect relationship of anemia with postpartum hemorrhage through uterine atony and it was statistically significant. Nyfløt et al. (2017) stated that anemia was 4.27 times more likely to increase the risk of postpartum hemorrhage.

The uterine organ required strong contractions during labor to stop bleeding due to the release of the placenta from attachment to the uterus for the process of uterine involution. Hemoglobin level $<11$ gram/dL would make the contraction of the uterine muscles weak when labor was directly causing postpartum bleeding (Saadah et al., 2017).

\section{AUTHOR CONTRIBUTION}

Siti Nur Hidayati collected, run the data analysis, and wrote the paper. Uki Retno Budi reviewed the manuscripts. Vitri Widyaningsih examined the conceptual framework and methodology.

\section{FUNDING AND SPONSORSHIP}

This study used the authors' independent costs.

\section{CONFLICT OF INTEREST}

The authors do not have any conflict of interest.

\section{ACKNOWLEDGMENT}

We would like to thank to the hospital that has assisted the process of the study.

\section{REFERENCE}

Biguzzi E, Franchi F, Ambrogi F, Ibrahim B, Bucciarelli P, Acaia B, Mannucci PM (2012). Risk factors for postpartum hemorrhage in a cohort of 6011 Italian women. Thrombosis Research Elsevier. 129(4): e1-e7. doi: 10.1016/j.thromres.2011.09.010.

Briley A, Seed PT, Tydeman G, Ballard H, Waterstone M, Sandall J, Poston L, et al. (2014). Reporting errors, incidence and risk factors for postpartum haemorrhage and progression to severe PPH: A prospective observational 
study. BJOG: An International Journal of Obstetrics and Gynaecology. 121(7): 8-76-888. doi: 10.1111/14710528.1258-8.

Carroll M, Daly D, Begley CM (2016). The prevalence of women's emotional and physical health problems following a postpartum haemorrhage: A systematic review. BMC Pregnancy and Childbirth. BMC Pregnancy and Childbirth. 16(1): 261. doi: 10.1186/s12884-0161054-1.

Dinas Kesehatan Provinsi Jawa Tengah (2017). Profil kesehatan Provinsi Jawa Tengah. Semarang. Available at: http://dinkesjatengprov.go.id/v2018/ dokumen/Profil2017/mobile/index.ht $\mathrm{ml} \# \mathrm{p}=1$.

Driessen M, Bouvier-Colle MH, Dupont C, Khoshnood B, Rudigoz RC, DeneuxTharaux C (2011). Postpartum Hemorrhage Resulting From Uterine- Atony After Vaginal Delivery.Obstetrics \& Gynecology. 117(1): 21-31. doi: 10.1097/aog.obo13e318202c845.

Fauziyah Y (2012). Obstetri Patologi (Obstetrics pathology). Yogyakarta: Nuha medika.

Fransiska RD, Respati SH, Mudigdo A (2017). Analysis of Maternal Mortality Determinants in Bondowoso District, East Java. Journal of Maternal and Child Health. 2(1): 76-88. doi: 10.26911/thejmch.2017.02.01.08.

Jekti RP, Suarthana E (2010). Risk factors of post partum haemorrhage in Indonesia. Health Science Journal. 2(2): 66-70. doi: 10.22435/hsji.v2i2 Des.67.66-70.

Knight M, Callaghan WM, Berg C,- Alexander S, Bouvier-Colle $\mathrm{MH}$, Ford JB, Oats $J$ (2010). Trends in post-partum hemorrhage in high resource countries: A review and recommendations from the international postpartum hemorrhage collaborative group. Obstetrical and Gynecological Survey. 65(4): 211-212. doi: 10.1097/01.ogx.0000371705.17102.c4.

Kramer MS, Dahhou M, Vallerand D, Liston R, Joseph KS (2011). Risk factors for postpartum hemorrhage: Can we explain the recent temporal increase? Journal of Obstetrics and Gynaecology Canada. 33(8): 810-819. doi: 10.1016/S1701-2163(16)34984-2.

Megasari M (2013). Faktor-faktor yang berhubungan dengan kejadian perdarahan pasca persalinan di RSUD Arifin Achmad Provinsi Riau Tahun 20092010 (Factors associated with post-delivery bleeding at Arifin Achmad Hospital in Riau Province 2009-2010). Jurnal Kesehatan Komunitas. 2(2): 72-77. https://doi.org/10.-25311/jkk.vol2.iss2.48.

Nyfløt LT, Sandven I, Stray-Pedersen B, Pettersen S, Al-Zirqi I, Rosenberg M, Vangen S (2017). Risk factors forsevere postpartum hemorrhage: Acase-control study. BMC Pregnancy and Childbirth. 17(1): 1-9. doi: 10.1186/s12884-016-1217-0.

Ononge S, Mirembe F, Wandabwa J, Campbell OM (2016). Incidence and risk factors for postpartum hemorrhage in Uganda. Reproductive Health. 13(1): 1-7. doi: 10.1186/s12978-016-0154-8.

Oyelese Y, Ananth CV (2010). Postpartum hemorrhage: Epidemiology, risk factors, and causes. Clinical Obstetrics and Gynecology. 53(1): 147-156. doi: 10.1097/GRF.obo13e3181cc406d.

Profil Kesehatan Indonesia (2016). Profil kesehatan RI 2015 (RI Health Profile 2015). doi: 10.1111/evo.12990.

Puspitasari R, Hastuti URB, Murti B (2017). Risk factors of postpartum hemorrhage in Bondowoso District, EastJava. Journal of Maternal and Child 
Health. 2(2): 177-187. doi: https://doi.org/10.26911/thejmch.2017.02.02.08.

Saadah M, Respati SH, Aristin OP (2017). Multilevel analysis on the risk fac-tors of post partum hemorrhage in Bondowoso, Central Java. Journal of Maternal and Child Health. 1(4): 205-213. doi: 10.26911/thejmch.2016.01.-04.01. Satriyandari Y, Hariyati NR (2017). Faktorfaktor yang mempengaruhi kejadian perdarahan postpartum (Factors that influence the incidence of postpartum hemorrhage). Journal of Health Studies. 1(1): 49-64. https://doi.org/10$.31101 /$ jhes.185.

Say L, Doris C, Alison G, Ozge T, Ann-Beth M, Jane D, Metin G, et al. (2014). Global causes of maternal death: A WHO systematic analysis.Lancet Glob Health. 2(6): 323-333. doi: 10.1016/S2214-109X(14)70227-X.

Sheldon WR, Blum J, Vogel JP, Souza JP, Gulmezoglu AM, Winikoff B (2014). Postpartum haemorrhage management, risks, and maternal outcomes: findings from the World Health Organization Multicountry Survey on Maternal and Newborn Health. BJOG: an international journal of obstetrics and gynaecology. 121: 5-13. doi: 10.1111/1471-0528.12636.

Sosa CG, Althabe F, Belizan JM, Buekens P (2009). Risk factors for postpartum hemorrhage in vaginal deliveries in a Latin-American population. Obstetrics and Gynecology. 113(6): 1313-1319. doi: 10.1097/AOG.obo13e3181a66bo5 .

Tort J, Rozenberg P, Traore M, Fournier P, Dumont A (2015). Factors associated with postpartum hemorrhage maternal death in referral hospitals inSenegal and Mali: A cross-sectional epidemiological survey.BMC Pregnancy and Childbirth. 15(1): 1. doi: 10.1186/s12884-015-0669-y.

Vendittelli F, Barasinski C, Pereira B, Lemery D (2016). Incidence of immediate postpartum hemorrhages inFrench maternity units: A prospective observational study (HERA study).BMC Pregnancy and Childbirth. 16(1): 1-9. doi: 10.1186/s12884-016-10087.

Widyaningsih V, Khotijah, Balgis (2017). Expanding the scope beyond mortality: burden and missed opportunities in maternal morbidity in Indonesia. Global Health Action. 10(1): 1-9. doi: 10.1080/16549716.2017.1339534.

Yuliati A, Soejoenoes A, Suwondo A, Anies A, Kartasurya MI (2018). Beberapa faktor kejadian perdarahan post-partum ibu bersalin yang dirawat di rumah sakit (Severeal maternal maternal post-partum bleeding factors that are hospitalized). Jurnal Epidemiologi Kesehatan Komunitas. 3(1): 7. https://doi.org/10.14710/j.e.k.k.v3i1.3101.

Yuliawati Y, Anggraini Y (2016). Hubungan riwayat preeklamsi, retensio plasenta, atonia uteri dan laserasi jalan lahir dengan kejadian perdarahan- postpartum pada ibu nifas (Relationship between history of preeclampsia, retention of the placenta, uterine atonia and road lacerations born with the incidence of postpartum hemorrhage in postpartum mothers). Jurnal Kesehatan. 6(1). doi:10.26630/JK.V-6I1.29. 